\title{
Correlates of Poverty in Pakistan: A Rural-Urban Comparative Analysis
}

Fatima Bashir ${ }^{1}$ and Muhammad Idrees ${ }^{2}$

\begin{abstract}
Policies aimed to eradicate poverty widely depend on the identification of factors that are associated with poverty. The understanding of poverty- generating factors provides meaningful insight to design policies for the emancipation of poverty. The purpose of this paper is to explore correlates of poverty in rural and urban areas of Pakistan. We explored the impact of various household, social and regional factors including dependency ratio, education, inequality and availability of health and education facilities. The results showed that dependency ratio and illiteracy cause poverty. Education, availability of health and education facilities and consumption inequality are found to be negatively associated with poverty. The rural-urban comparison revealed that for poverty eradication, education is relatively more effective in urban areas while the dependency ratio is more detrimental in rural areas. The impact of social factors on poverty depicts more reduction in urban poverty due to the availability of better health and educational facilities in these areas. As far as the consumption inequality is concerned, the marginal effect shows a relatively higher impact in urban areas probably due to the diversified nature of job and education opportunities, resulting in higher consumption inequality in these areas.
\end{abstract}

Keywords: Poverty, Education, Inequality, Dependency Ratio

\section{JEL Classification: I32}

\section{Introduction}

Poverty alleviation continues to be the utmost goal of the policy agenda in Pakistan. Despite a considerable decline in poverty over past years; it is still acute and widespread in Pakistan. Pakistan Economic Survey (2017-18) reported that $24.3 \%$ of the population still lived below the poverty line in 2015-16. These statistics indicate that almost every 4tindividual in Pakistan is living below the poverty line and unable to meet the necessities of life. Thus, it is important to formulate policies to combat poverty at a grass root level. The efficacy of policies widely depends on the strong understanding of factors that are responsible for the

\footnotetext{
${ }^{1}$ Ph.D. Scholar, School of Economics, Quaid-i-Azam University, Islamabad, Pakistan.

${ }^{2}$ Professor, School of Economics, Quaid-i-Azam University, Islamabad, Pakistan.

Corresponding author's Email: midrees@qau.edu.pk
} 
prevalence of poverty. Exploring the major causes of poverty will help to address these factors by formulating strategies in a true sense (Majeed and Malik, 2015). Pakistan is a country characterized by wide variation in basic needs and living standards across regions. Rural and urban poverty differ in many ways, with distinct regional concerns associated with these areas. Despite several initiatives taken by the Government, the gap between urban and rural poverty is still huge in Pakistan (Idrees, 2017).

In Pakistan, a significant number of empirical attempts have been made to measure poverty. Nevertheless, very few studies are conducted to identify the correlates of poverty. In this regard, studies by Mahmood et al. (1991), Azid and Malik (2000), Arif et al. (2011), Majeed and Malik (2015), Khurram and Hassan (2019) and Shaikh et al. (2020) are worth mentioning. These studies are considerable of diverse nature; different determinants have been used by researchers covering different time periods and regions. A summary of correlates of poverty considered by various studies is given in Table 1 .

The existing literature in Pakistan reveals that most of the studies have explored correlates of poverty at the national level and a little attention has been devoted to the regional cleavage. Urban and rural poverty is often caused by the same factors, but there are several important differences as the cost of living is not uniform across the regions of Pakistan. It is thus crucial to take into account these differences for the identification of factors. The present research is therefore an attempt to bridge the gap in the earlier literature by estimating the region-specific correlates of poverty in Pakistan. These factors will help to ascertain better insights into poverty in urban and rural areas of Pakistan. This has broader implications for targeting interventions and allocating resources to each region. Further, the comparison of two households is meaningless without considering the number of members in a household. Contrary to previous studies, we standardize these factors by incorporating household size in the analysis. Moreover, this research is novel in the sense that social and regional characteristics are determined at a division level, which is hardly considered in previous studies.

Most recently, Bashir and Idrees (2018) estimated region-specific poverty estimates for rural and urban segments of all provinces ${ }^{3}$. The present study shall utilize their estimates to explore correlates of poverty in rural and urban segments of Pakistan. The research is organized as follows: Section two describes the

\footnotetext{
${ }^{3}$ This study estimated region-specific poverty lines through Cost of Basic Need Approach for rural and urban areas of all provinces. The poverty lines were then used to measure incidence of poverty. The estimates of Head Count Indices are reported in Annexure: I.
} 
framework of the analysis, which includes data source, methodology and the econometric model. Section three discusses the result while section four summarizes and provides concluding remarks.

\section{Framework of Analysis}

In this section, we shall discuss the empirical framework of the research which includes data source, methodology and the econometric model.

\subsection{Data Source}

The data source of the present study is the Household Integrated Income and Consumption Survey (HIICS) conducted and published by the Pakistan Bureau of Statistics, Government of Pakistan. HIICS, a special survey planned for 201516, is a combination of Household Integrated Economic Survey (HIES) and Family Budget Survey. The HIICS is designed to meet the requirements of rebasing and generating HIES survey for better coverage and quality of data in the overall context of poverty reduction strategy. HIES survey provides detailed information on household income, savings, liabilities, and consumption expenditure and consumption patterns. The universe of the HIICS/ HIES consists of all urban and rural areas of the four provinces of Pakistan excluding FATA, restricted military areas. To capture the impact of social factors like education and health care facilities, we use data from Provincial Development Statistics of each province. These are accessible sources that contain comprehensive information on various facilities available in the administrative divisions of each province.

\subsection{Construction of Variables}

The focus of this research is to investigate a number of factors that cause or control poverty at the regional level. Based on the poverty estimates of Bashir and Idrees (2018), the dependent variable (poor) is a binary variable with ' 1 ' for poor households and ' 0 ' otherwise. Regarding correlates of poverty, we consider various household, social and regional factors that may affect poverty as categorized by Haughton and Khandker (2009). ${ }^{4}$ In specific we shall consider the following correlates of poverty:

\footnotetext{
${ }^{4}$ It is a comprehensive study and covers regional characteristics along with individual and household characteristics to capture region-specific correlates of poverty.
} 
Table 1: Correlates of Poverty Explored by Various Studies in Pakistan

\begin{tabular}{|c|c|c|c|c|c|c|c|c|c|}
\hline \multirow[b]{2}{*}{ Study } & \multicolumn{9}{|c|}{$\begin{array}{cc}\text { Correlates of Poverty } \\
\end{array}$} \\
\hline & Education & $\begin{array}{c}\text { Region/ } \\
\text { Province }\end{array}$ & $\begin{array}{c}\text { Dependency } \\
\text { Ratio }\end{array}$ & $\begin{array}{c}\text { Household } \\
\text { Size }\end{array}$ & $\begin{array}{c}\text { Age of } \\
\text { Head }\end{array}$ & $\begin{array}{c}\text { Gender of } \\
\text { Head }\end{array}$ & $\begin{array}{c}\text { Employment } \\
\text { Status of Head }\end{array}$ & $\begin{array}{c}\text { Number of } \\
\text { Earner }\end{array}$ & Miscellaneous \\
\hline Mahmood et al. (1991) & $(-)$ & & $(+)$ & $(+)$ & & & & & Family Type: Nuclear (+) or joint (-) \\
\hline Shirazi(1995) & $(-)$ & $(-)$ & & $(+)$ & & & & $(-)$ & Charity Recipient (-) \\
\hline Amjad and Kemal (1997) & & & & & & & & & $\begin{array}{l}\text { Macroeconomic variables, Real GNP (-), } \\
\text { Wages (-), Remittances (-), Subsidies (-) }\end{array}$ \\
\hline Azid and Malik (2000) & $(-)$ & & $(+)$ & $(+)$ & ** & & & & $\begin{array}{l}\text { Transport, health, credit, technological } \\
\text { variables (-), Ratio of female to male worker } \\
(-)\end{array}$ \\
\hline Qureshi and Arif (2001) & $(-)$ & $(-)$ & & $(+)$ & $(-)$ & ** & & $(-)$ & $\begin{array}{l}\text { Farm status of household (-), Residency } \\
\text { Status urban (-), Remittances (-) }\end{array}$ \\
\hline Kemal et al. (2001) & $(-)$ & $(-)$ & & $(+)$ & $(-)$ & $* *$ & & $(-)$ & $\begin{array}{l}\text { Farm status (-), Residency Status (-), } \\
\text { Remittances (-) }\end{array}$ \\
\hline Khalid et al. (2005) & $(-)$ & & & $(+)$ & $(-)$ & $(+)$ & & & $\begin{array}{l}\text { Family Type: Nuclear (-), Assets (-), Loans } \\
(-)\end{array}$ \\
\hline Arif and Bilquees (2007) & $(-)$ & $(-)$ & & $(+)$ & $(-)$ & $(-)$ & $(-)$ & $(-)$ & $\begin{array}{l}\text { Ownership of house (+), land ownership (-), } \\
\text { sharecropping (+), Livestock ownership (-), } \\
\text { Zakat (+), Remittances (-), loans (+) }\end{array}$ \\
\hline Hashmi et al. (2008) & $(-)$ & & $(+)$ & $(+)$ & $(-)$ & & & & $\begin{array}{l}\text { Remittances (-), Ownership of livestock, } \\
\text { tractor and land (-) }\end{array}$ \\
\hline Chaudhry (2009) & $(-)$ & & $(+)$ & $(+)$ & $(-)$ & & & & $\begin{array}{l}\text { Participation rate (-), gender ratio (-), } \\
\text { physical Asset, Landholding }(-)\end{array}$ \\
\hline Awan and Iqbal (2010) & $(-)$ & & & $(+)$ & & & & & $\begin{array}{l}\text { Gas/ Telephone/ Water, Sewerage (-), } \\
\text { Experience (-) }\end{array}$ \\
\hline Naz et al.(2010) & $(-)$ & & $(+)$ & & ** & $(-)$ & $(-)$ & ** & Land/livestock/ Participation (-) \\
\hline Irfan (2011) & & & & & & & & & $\begin{array}{l}\text { GDP (-), Remittances (-), Population (+), } \\
\text { Wages(-), Inflation(+) }\end{array}$ \\
\hline Arif et al. (2011) & & $(+)$ & $(+)$ & $(+)$ & $(-)$ & $(-)$ & & & $\begin{array}{l}\text { Education of head(-), } \mathrm{Age}^{2} \text { of head (+), } \\
\text { Assets(-) }\end{array}$ \\
\hline Khalid and Akhtar (2011) & & $(-)$ & $(+)$ & & $(-)$ & $(-)$ & $(-)$ & & $\begin{array}{l}\text { Marital Status (-) and education of head (-), } \\
\text { illiterate (+), remittances(-) }\end{array}$ \\
\hline Pervez and Rizvi (2014) & & & & & & & & & $\begin{array}{l}\text { Macroeconomic variables: Agricultural } \\
\text { growth (+), Trade openness (+), Employment } \\
(+) \text {, Remittances, FDI and Inflation (-). }\end{array}$ \\
\hline Cheema and Sial (2012) & $(-)$ & & & $(+)$ & $(-)$ & & & & $\begin{array}{l}\text { Remittances (-), Livestock/ Sewing machine/ } \\
\text { Land Ownership (-) }\end{array}$ \\
\hline Majeed and Malik (2015) & $(-)$ & $(+)$ & & $(+)$ & $(+)$ & $(+)$ & $(-)$ & & $\begin{array}{l}\operatorname{Age}^{2}(-), \text { Remittances }(-), \text { Work Experience } \\
(-)\end{array}$ \\
\hline
\end{tabular}


Awan and Iqbal (2014)

Cheema and Sial (2014)

Haq et al. (2015)

Jamal (2015)

Ali and Ali (2018)

Khurram and Hassan (2019)

Shaikh et al. (2020)

Ahmad and Awan (2021)

Sewerage/ Water/ telephone/ Gas (-), Work Experience (-)

Animal for transportation/ Residential and Commercial Building (-), Head Occupation

Head Illiterate (-),Female -Male Ratio $(+)$,Asset(-),Landholding(-), Participation rate $(+)$, Person per room $(+)$

$(-) \quad$ Asset / Roof quality /Room per Person (-)

Macroeconomic variables: Unemployment rate, budget deficit, government expenditure, exchange rate and inflation.

(-) Female/ male ratio (+), Education of head (-

), Landholding size (-), Asset (-)

Sources of drinking water, types of treatments, defecation, school enrolment, per capita income.

GDP (-), Tax (-), Population (+), Inflation (-

Where $* *$ refers to insignificant results. 


\subsubsection{Dependency Ratio}

It is the proportion of dependent family members and thus high dependency ratio indicates a high burden on the working members of the household. In general poverty and dependency ratio are closely tied. A higher dependency ratio is indicative of lower household per capita earning and thus affects overall household consumption expenditures. A large amount of income is required by the household with more dependents to spend as compared to a household with a lower dependency ratio (Simler et. al., 2004; Chaudhry et al., 2009 and Cheema and Sial, 2014). The present study measures the dependency ratio as the ratio of non-earners to total household members.

Dependency Ratio $=\frac{\text { Non Earning Household Members }}{\text { Total Household Members }}$

The dependency ratio ranges between zero and one, with 'zero' indicating that all household members are earners and 'one' showing that there is no earning member in a household.

\subsubsection{Proportion of Graduates in a Household}

Education is an important factor that plays a vital role in alleviating poverty. Education has both direct and indirect effect on poverty (Psacharopoulos and Woodhall, 1985). Higher education helps in reducing poverty by increasing productivity, improving income, health and overall wellbeing of household (for instance, Shirazi, 1995; Nasir and Nazli, 2000; Awan and Iqbal, 2010; Cheema and Sial, 2012 and Khatun (2015). In order to capture the impact of education, we consider graduation (14 years of successful education) as a benchmark of higher studies. The proportion of adult household members (age 18 years or more) with a graduation degree shall be considered as a proxy of education.

Proportion of Graduates in a Household $=\frac{\text { Members age } 18 \text { or more with at least } 14 \text { years of successfull education }}{\text { All Household Members with age } 18 \text { years or more }}$

\subsubsection{Proportion of Illiterates in a Household}

Generally speaking, illiterates are relatively less productive members of a society which often leads to low income, precarious financial position and transmits intergenerational illiteracy in a family. In this study, we consider primary ( 5 years of successful education) as a benchmark of literacy. Therefore, to analyze the impact of illiteracy on poverty, the proportion of illiterates in a household is calculated by taking individuals of age at least 5 years who are neither enrolled nor primary passed.

Proportion of Illiterates in a Household $=\frac{\text { Members age } 5 \text { years or more neither enrolled nor primary pass }}{\text { All Household Members with age } 5 \text { years or more }}$ 


\subsubsection{Gender of Household Head}

It is a well-known fact that males and females have different employment opportunities and other income generating capacities. In Pakistan, female heads often face discrimination in education, earnings and access to basic services. There is a lack of consensus regarding the poverty status of the gender of a household headed by male or female. According to Aliber (2003), Geda et al. (2005) and Haq et al. (2015), households headed by males are less prone to poverty as compared to those headed by a female. On the contrary, Majeed and Malik (2015) found less poverty in the household headed by females as compared to male-headed households in Pakistan. In this study, we shall treat the gender of the household head as a binary variable with 1 for male and zero otherwise.

\subsubsection{Education of Household Head}

The education of the household head is another important correlate of poverty. Education attained by the head of household improves the living standard of an entire household. In general, there is a negative relation between the highest education attained by the head of household and poverty (Chaudhry, 2009). Educational attainment of the head is considered as a successful year of schooling of the household head.

\subsubsection{Availability of Schools}

Apart from household characteristics, social and regional factors also play a vital role in causing or controlling poverty. In this regard, access to education is an important factor. In general, the poor may not afford to send their children at farflung places to attain education. Therefore, the availability of schools can be a good proxy to capture the impact of access to education. We shall consider a number of secondary schools available per thousand population with age between 10 and 18 years. It is pertinent to mention here that the availability of secondary schools is separately measured for rural and urban segments of all administrative divisions.

Availability of Schools $=\frac{\text { Number of Secondary Schools in Administrative Division }}{\text { Population with age between } 10 \text { and } 18 \text { years }}$

\subsubsection{Availability of Health Care Facilities}

Another important factor is the availability of health care facilities. Access to better education and improved health facilities enhance the productivity and earning capacity of the household and thus reduce poverty (Ali and Ahmad, 2013). Health is proxied by a number of government hospitals in the urban areas while number of Rural Health Centers in the rural areas. The mere comparison of hospitals may not be meaningful, as all hospitals do not have the same capacity. 
Therefore, hospital availability is calculated by a total number of beds in the hospital per 1000 population to standardize the estimates. These two social indicators are separately calculated for rural and urban segments of all administrative divisions.

Table 2: Construction of Variables for Correlates of Poverty in Pakistan

\begin{tabular}{|c|c|}
\hline Variables & Construction of Variables \\
\hline \multicolumn{2}{|l|}{ Dependent Variable } \\
\hline Poverty status of household & ' 1 ' if the Household is poor and zero otherwise \\
\hline \multicolumn{2}{|l|}{ Explanatory Variables } \\
\hline Dependency Ratio & Ratio of non-earners to total members. \\
\hline Education & $\begin{array}{l}\text { Proportion of adults (age } 18 \text { years or more) with at least } 14 \text { years of successful } \\
\text { education (Graduation) }\end{array}$ \\
\hline Illiterate & $\begin{array}{l}\text { Proportion of Illiterates in a household (at least } 5 \text { years of age) neither enrolled } \\
\text { nor primary passed }\end{array}$ \\
\hline Gender of Head & Male $=1$, Female $=0$ \\
\hline Education of Head & Successful years of schooling of household head \\
\hline Availability of Schools & $\begin{array}{l}\text { Number of secondary schools available per } 000 \text { population (age } 10-18 \text { ) in } \\
\text { administrative division }\end{array}$ \\
\hline Availability of Hospitals & $\begin{array}{l}\text { Number of beds available per } 000 \text { population of administrative division for } \\
\text { urban areas and Number of Rural Health Centers in administrative division for } \\
\text { rural areas }\end{array}$ \\
\hline Consumption Inequality & $\begin{array}{l}\text { Gini Coefficient of Income Inequality in Rural and Urban segments of all } \\
\text { administrative divisions }\end{array}$ \\
\hline
\end{tabular}

\subsubsection{Consumption Inequality}

Disparities in consumption or income may also affect poverty. The literature shows that there exists a strong relationship between poverty and inequality, both positive and negative. In specific, we want to analyze how inequality in an administrative division affects poverty. In this context, we shall calculate Gini Coefficient to measure inequality in the rural and urban segments of each administrative division of Pakistan. According to Rao (1969), Gini Coefficient can be mathematically written as:

$G=1-\sum_{i=1}^{n-1} P S_{i}\left(C S_{i}+C S_{i-1}\right)$

Where, $P S_{i}$ is the cumulative population share and $C S_{i}$ is the cumulative income share of the $i^{\text {th }}$ income unit, when all income units are arranged in ascending order of income. Correlates of poverty considered in this study are summarized in Table 2. 


\subsection{Econometric Model}

Since the dependent variable is binary in this study, with ' 1 ' for poor and ' 0 ' otherwise, therefore, Logistic model and Probit model can be two competing options. The logit model is based on the cumulative distribution function of the logistic distribution and the Probit model considers the cumulative distribution function of standard normal distribution. Both models yield similar inferences, yet many researchers prefer the Logit model because it is relatively simple and directly interpretable (McCullagh and Nelder, 1989). Therefore, the present study shall apply the Logit model to estimate correlates of poverty at the regional level in Pakistan. In recognition of the fact that rural and urban areas differ widely in terms of standard of living and other factors, we shall run separate regressions for urban and rural areas.

$P_{i}=\alpha_{o}+\alpha_{1}$ (Prop.Illiterate) $i+\alpha_{2}$ (Prop.Graduate) $i+$ $\alpha_{3}$ (Dependency Ratio $) i+\alpha_{4}($ Head Gender $) i+\alpha_{5}$ (Head Education $) i+$ $\alpha_{6}$ (Consumption Inequality) $j+\alpha_{7}$ (Rural Health Centers / Hospitals $) j+\alpha_{8}$ (Schools $) j+\mu_{i}$

Where, $\mathrm{i}=1,2, \ldots$ (households) and $\mathrm{j}=1,2, \ldots$ (administrative districts), Rural Health Centers are considered for rural areas and Hospitals are considered for urban areas.

The interpretation of odd ratios is cumbersome. Therefore, we shall estimate the marginal effects.

\section{Results and Discussions}

In this section, we present the results of our analysis. This section comprises three sections. The correlates of poverty in urban and rural areas of Pakistan are presented in Section 3.1 and Section 3.2, respectively. Section 3.3 presents the comparative analysis of the correlates of poverty across rural and urban areas of Pakistan.

\subsection{Correlates of Poverty in Urban Areas of Pakistan}

Table 3 summarizes the estimates for the correlates of poverty by using a regression for urban areas in Pakistan. The results show that all the explanatory variables in our model have their expected signs. Empirical results are strongly consistent with the theoretical considerations and coefficients are highly significant. 
Table 3: Marginal Effects of Logit Regression for Correlates of Poverty in Urban Areas of Pakistan

\begin{tabular}{lccc}
\hline Explanatory Variables & $\begin{array}{c}\text { Marginal } \\
\text { Effects }\end{array}$ & Z - values & p - values \\
\hline Dependency Ratio of Household & +0.2924916 & 15.58 & 0.000 \\
Proportion of Illiterates in a Household & +0.2509111 & 18.27 & 0.000 \\
Proportion of Graduates in a Household & -0.8420935 & -21.01 & 0.000 \\
Gender of Household Head & +0.1181981 & 17.33 & 0.000 \\
$\begin{array}{l}\text { Education of Household Head } \\
\text { Number of beds in Hospitals, available per 000 population } \\
\text { of administrative division }\end{array}$ & -0.0106895 & -13.70 & 0.000 \\
$\begin{array}{l}\text { Number of Secondary Schools available per 000 } \\
\text { population (age 10-18) of administrative division }\end{array}$ & -1.870381 & -8.65 & 0.000 \\
$\begin{array}{l}\text { Gini Coefficient of Consumption Inequality } \\
\text { in administrative division }\end{array}$ & -0.3410508 & -8.47 & 0.000 \\
Psedu-R & & & 0.000 \\
\hline
\end{tabular}

Source: Self Estimations

The variable dependency ratio has a positive impact on poverty, implying that the more the dependent individual in a household, the higher the chances of poverty. The marginal effect implies that with a one percent increase in dependency ratio (proportion of unemployed members), the probability of a household being poor increases by 0.2924 percent. Now we shall convert it into the number of household members. The average household size in urban areas of Pakistan is 6.37 implying that on average one member comprises 15.698 percent of the household. The average effect is obtained by taking the product of marginal effect $(0.2924)$ and average member (15.698) and the corresponding unit change is 4.55 percent points. ${ }^{5}$ It indicates that the likelihood of being poor increases by 4.55 percent point with the increase in one dependent in a household. This result is consistent with previous literature (for instance, Mahmood et al., 1991).

The estimated marginal effect of illiteracy implies that with a one percent increase in illiterates, the probability of a household being poor increases by 0.2509 percent. One percent increase in the number of illiterates is not a good measure; therefore, we convert it into a number of illiterates. Since the average household size in urban areas is 5.61, one member (out of 5.61) is 17.83 percent of the average household size. ${ }^{6}$ Therefore, in terms of unit change, with the increase in one illiterate in a household the probability of household to be poor increases by 4.47 percent points. The findings are consistent with the general perception that poverty increase with the increase in the illiteracy rate.

${ }^{5}$ Considering all individuals.

${ }^{6}$ Considering individuals with age 5 years or more 
Besides illiteracy, another variable that affects poverty is depicted by the proportion of graduation passed (with education 14 years or more) adult members. The coefficient of this variable has an anticipated negative effect on poverty, implying that the greater the proportion of educated adults in a household, the lower is the probability of poverty. The coefficient implies that with a one percent increase in a number of adults with education 14 years or more, the probability of a household being poor decreases by 0.842 percent. To make it more meaningful, we convert it into a number of graduates (education 14 years or more). Since the average number of adults in the household is 3.604, one adult out of 3.604 is 30.26 percent; therefore, the corresponding average effect is 25.5 percent points. ${ }^{7}$ It indicates that with the increase in one graduate in a household the probability of the household being poor decreases by 25.5 percent points. The result is consistent with the studies of Khalid et al. (2005), Arif and Bilquees (2007) and Cheema and Sial (2012, 2014).

The statistics of the gender of the household head show that likelihood of a male headed household being poor is 11.82 percent points more than a household headed by female. The results indicate that, despite the prevalence of the traditional patriarchal system, discrimination and barriers to women's employment, female headed households are less prone to poverty. This is an awkward finding, but the microanalysis of data revealed that a significant number of female-headed households are a widow with a large number comprised of relatively wealthy households. ${ }^{8}$ Further, it is also observed that a significant number of women headed households have earning members including son, brother or daughter of head. This finding is consistent with the previous literature (for instance, Qureshi and Arif, 2001; Awan and Iqbal, 2010; Yetna et al., 2012; Adetayo, 2014 and Majeed and Malik, 2015), which showed the negative relationship between poverty and female headed households.

The relation between education of the head of household and poverty status is found to be negative in urban areas. The statistic shows that with an additional year of schooling the probability of household to be poor decreases by 1.07 percentage points. It implies that education of the head of the household lowers the chances of household fall into poverty. These findings are consistent with the earlier literature (for instance, Shirazi, 1995; Jamal, 2005; Haq, 2005; and Khurram and Hassan, 2019).

\footnotetext{
${ }^{7}$ We have considered members with age 18 or more

${ }^{8} 56 \%$ of female headed households are widowed in the entire sample.
} 
The marginal effect of health facilities in a region is -1.8703 which indicates that unit increase in a number of hospital beds per thousand decreases poverty by 1.8703 percentage points. An attempt is made to explore the impact of education facilities in poverty eradication. The results show that chances of a household being poor are likely to decrease by 0.341 percentage points with an additional secondary school available per thousand population (age between $10-18$ ). This indicates that better education facilities can be effective in eradicating poverty. Arif and Iqbal (2009) found that provision of education and health services contributed to an increase in income and a reduction in income.

The marginal effects of consumption inequality show that a percent increase in consumption inequalities in division (as measured through Gini coefficient) leads to 0.303 percent decrease in poverty. There could several reasons of this negative relation, such as inequality providing greater incentives in businesses and boosting overall investment in the economy. Inequality can be translated into employment opportunities, consumer spending, creating more business activity and expansion in economic activities which is trickled down to poor (Lazear and Rosen, 1981 and McKnight et al., 2017). Frank (2009) argued that inequality reduces poverty if it is skewed in favor of income at the top of the distribution. This phenomenon can be observed in Pakistan where the rich are getting richer and the poor are marginally pushed out of the poverty trap. Moreover, it is pertinent to mention that the widening gap between the rich and the middle class has substantially increased income and consumption inequalities over time. At the same time, numerous social safety programs played a significant role in tackling poverty and thereby improve the living conditions of the poor. ${ }^{9}$

This completes our discussion on correlates of poverty in urban areas, we now move to the analysis of poverty correlates in rural areas of Pakistan.

\subsection{Correlates of Poverty in Rural Areas of Pakistan}

The marginal effects of Logit regression in rural areas of Pakistan are presented in Table 4. The variable of dependency ratio shows that with a one percent increase in the dependency ratio, the probability of a household being poor increases by 0.318 percent. The average household size in rural areas is 6.75 indicating that on average 14.81 percent of members comprise one individual. Therefore, in terms of unit change, with the increase in one dependent in a household, the probability of a household being poor increases by 4.71 percent.

\footnotetext{
${ }^{9}$ In 2010-11, the average income of household belonging to top quintile was 2.15 times the average household income of household belonging to third quintile, which jumped to 3.25 in 2015-16. Poverty during same period declined by 8.25 percentage
} 
Hashmi et al. (2008), Arif et al. (2011) and Haq et al. (2015) also found that a higher dependency ratio is positively associated with poverty in rural areas.

The marginal effect of illiteracy implies that with a one percent increase in illiterates, the probability of a household being poor increases by 0.171 percent in rural areas. As already mentioned in the previous section, one percent increase in number of illiterates is difficult to interpret, so we convert it into a number of illiterate members. The average household size in rural areas is 5.79 (considering members with age at least 5 years); therefore, in terms of unit change, with the increase in one illiterate in a household the probability of household being poor increases by 2.95 percent points. The literature (for instance, Arif et al. 2011) also supports the similar finding.

The coefficient of proportion of graduates implies that with a one percent increase in graduates (education 14 years or more), the probability of household to be poor decreases by 0.698 percent. In rural areas of Pakistan, the average number of household members age 18 or above is 3.4 , which indicates that one such member is 29.41 percent of the household. Therefore, the probability of a household to be poor decreases by 20.53 percent points with an additional graduate member. This is in conformity with the studies of Hashmi et al. (2008), Arif et al. (2011) and Haq et al. (2015).

Table 4: Marginal Effects of Logit Regression for Correlates of Poverty in Rural Areas of Pakistan

\begin{tabular}{lccc}
\hline Explanatory Variables & Marginal Effects & z - values & p - values \\
\hline $\begin{array}{l}\text { Dependency ratio of a household } \\
\text { (proportion of dependent members) }\end{array}$ & +0.3187796 & 13.93 & 0.000 \\
$\begin{array}{l}\text { Proportion of illiterates } \\
\text { in a household }\end{array}$ & +0.1710197 & 9.86 & 0.000 \\
$\begin{array}{l}\text { Proportion of graduates } \\
\text { (education 14 years or more) in a household }\end{array}$ & -0.6981499 & -4.97 & 0.000 \\
$\begin{array}{l}\text { Gender of head } \\
\text { (one for male) }\end{array}$ & +0.0799713 & 11.41 & 0.000 \\
$\begin{array}{l}\text { Education of head } \\
\text { (successful years of schooling) }\end{array}$ & -0.0051431 & -5.04 & 0.000 \\
$\begin{array}{l}\text { Number of Rural Health Centers } \\
\text { in administrative division }\end{array}$ & -0.002667 & -9.76 & 0.000 \\
$\begin{array}{l}\text { Number of schools available per 000 population (age } \\
\text { 10 - 18) in administrative division }\end{array}$ & -0.2196802 & -4.90 & 0.000 \\
$\begin{array}{l}\text { Gini coefficient of consumption inequality } \\
\text { for administrative division }\end{array}$ & -0.0991174 & -2.32 & 0.020 \\
Psedu-R & & & \\
\hline
\end{tabular}

Source: Self Estimations

The gender of household heads in rural areas shows that the probability of a male headed household being poor is 7.99 percent more than a household headed 
by a female. Like urban areas, the impact of head's education is found to be negative in rural areas. The marginal effect shows that with an additional year of schooling the probability of household head being poor decreases by 0.51 percentage points.

The results of social characteristics show that with an additional RHC in a division, the probability of a household being poor decreases by 0.002 percentage points. Our next variable is the number of secondary schools available per thousand population (age 10 to 18 years). The result depicts that the likelihood of a household being poor decreases by 0.22 percent with an additional school.

The consumption inequality variable indicates that a percent increase in inequality leads to 0.11 percent decrease in poverty in rural areas, implying that inequality has a negative effect on poverty in rural areas. Thus, the higher the inequality, the lower is the likelihood of being poor.

\subsection{Comparative Analysis of the Correlates of Poverty Across Rural and Urban Areas of Pakistan}

Table 5 gives a comparative analysis of the correlates of poverty across rural and urban areas of Pakistan.

Table 5: Comparative Analysis of the Correlates of Poverty across Rural and Urban Areas of Pakistan.

\begin{tabular}{|c|c|c|}
\hline \multirow[t]{2}{*}{ Description of Variables } & $\begin{array}{l}\text { Average Effect } \\
\text { Percentage Points }\end{array}$ & Measured \\
\hline & Urban Areas & Rural Areas \\
\hline $\begin{array}{l}\text { With an additional illiterate member (age } 5 \text { years or more) the probability of a } \\
\text { household to be poor is likely to increase by }\end{array}$ & 4.47 & 2.95 \\
\hline $\begin{array}{l}\text { With an additional member (age } 18 \text { years or more) having at least } 14 \text { years of } \\
\text { successful education, the probability of a household to be poor is likely to } \\
\text { decrease by }\end{array}$ & 25.5 & 20.53 \\
\hline $\begin{array}{l}\text { With an additional dependent member, the probability of a household to be poor } \\
\text { is likely to increase by }\end{array}$ & 4.55 & 4.71 \\
\hline $\begin{array}{l}\text { Likelihood of a male headed household to be poor in comparison of female } \\
\text { headed household }\end{array}$ & 11.82 & 7.99 \\
\hline $\begin{array}{l}\text { With an additional year of Head's education, the probability of a household to be } \\
\text { poor is likely to decrease by }\end{array}$ & 1.07 & 0.51 \\
\hline $\begin{array}{l}\text { With an additional bed per thousand persons in administrative division, the } \\
\text { probability of a household to be poor is likely to decrease by }\end{array}$ & 1.87 & - \\
\hline $\begin{array}{l}\text { With an additional Rural Health Center in administrative division, the probability } \\
\text { of a household to poor is likely to decrease by }\end{array}$ & - & 0.22 \\
\hline $\begin{array}{l}\text { With an additional secondary school in administrative division, the probability of } \\
\text { a household to be poor is likely to decrease by }\end{array}$ & 0.34 & 0.22 \\
\hline $\begin{array}{l}\text { A percentage increase in consumption inequality across household in } \\
\text { administrative division, the probability of a household being poor is likely to } \\
\text { decrease by }\end{array}$ & 0.30 & 0.11 \\
\hline
\end{tabular}

We observed from the above analysis that variables of education, health, dependency ratio, gender of household head and consumption inequality have 
similar effects across rural and urban areas of Pakistan. However, the following interesting differences are worth mentioning.

First, although education is important both in rural and urban areas, higher education is found to be extremely effective in urban areas of Pakistan. An overwhelming majority of the employment opportunities in urban areas are educational- based, such as the financial sector and public administration, which drive up demand for highly educated and skilled labor. On the contrary, agriculture and small businesses are primary source of income and employment for rural households. There may be less scope of higher education and skills in these sectors. Thus, higher education contributes to enhance income and consequently reduce poverty in urban areas.

Second, the dependency ratio is more closely associated with poverty in rural areas. The dependency ratio is often higher in rural areas because of many economic and social reasons. People living in rural areas have a larger family to support them in household expenditures especially in old age. Rural households are mostly engaged in agriculture and low paid jobs, which make them difficult to bear everyday expenses due to relatively low earnings. Another reason could be that rural households particularly women are less educated and unaware of the family planning benefits. Moreover, early marriages seem to escalate poverty in rural areas due to cultural constraint, which consequently leads to a higher dependency ratio.

Third, consumption inequality is an inherent characteristic of urban areas. The urban population is highly diversified with regards to education and skills. They often spend a higher proportion of their expenditures on consumption items such as restaurants, clothing, travel, recreation and entertainment. These economic activities automatically generate higher employment opportunities and reduce poverty due to trickle- down effect.

In short, the results confirm that education is the fundamental factor in reducing poverty, whereas illiteracy certainly has a positive impact on poverty in urban and rural areas of Pakistan. Education (particularly higher education) is an essential tool for the eradication of poverty. Improvement in accessible educational facilities, investment in infrastructure, free or subsidized education material with qualified teachers, involvement of the private sector can provide a significant contribution in reducing poverty. Similarly, the dependency ratio needs to be addressed by designing policies to increase employment opportunities, creating credit access, revamping skill development programs and infrastructure and limited family awareness. Universal access to quality hospitals and schools should be 
provided, especially in rural areas for enhancing the quality of life of unprivileged and needy persons.

\section{Conclusion}

In this research, an attempt has been made to explore the correlates of poverty for urban and rural areas of Pakistan. By employing the Logit model, we have examined the impact of various household, social and regional characteristics on poverty. The findings revealed that education, better access to schools and hospitals and inequality are prominent factors in reducing poverty. On the other hand, illiteracy, dependency ratio and male headed households have a positive impact on poverty.

Comparing the marginal effects of various correlates across urban and rural areas, we found that education in urban areas is relatively more effective in eradicating poverty. Furthermore, there are evident differences regarding the marginal effect of the dependency ratio. The statistics indicate that with an additional dependent member, the probability of a household being poor certainly is more in rural areas. In case of consumption inequality, a percentage increase in inequality decreases the probability of a household being poor significantly more in urban areas than in rural ones.

The results suggest that improvement in accessible educational facilities, investment in infrastructure, free or subsidized education material with qualified teachers, involvement of the private sector could provide a significant contribution in reducing poverty. Similarly, the dependency ratio needs to be addressed by designing policies to increase employment opportunities, creating credit access, revamping skill development programs and infrastructure and limited family awareness. Universal access to quality hospitals and schools should be a matter of great priority for addressing poverty, in particularly, rural areas. 


\section{References}

Adetayo, A. (2014). Analysis of farm households poverty status in Ogun states, Nigeria. Asian Economic and Financial Review, 4(3), 325-340.

Ahmad, A., \& Awan, A. G. (2021). Impact of taxation on poverty in Pakistan. International Journal of Management, 12(6), 260-278.

Aliber, M. (2003). Chronic poverty in South Africa: Incidence, causes and policies. World Development, 31(3), 473-490.

Ali, S., \& Ahmad, N. (2013). Human capital and poverty in Pakistan: Evidence from the Punjab province. European Journal of Science and Public Policy, $11,36-41$.

Amjad, R., \& Kemal, A. R. (1997). Macroeconomic policies and their impact on poverty alleviation in Pakistan. The Pakistan Development Review, 36(1), 39-68.

Arif, G. M., \& Iqbal, N. (2009). Infrastructure and poverty nexus: The case of rural Pakistan in socio-economic challenges faces by Pakistan. Proceedings of the Islamic International University, Islamabad.

Arif, G. M., \& Bilquees, F. (2007). Chronic and transitory poverty in Pakistan: Evidence from a longitudinal household survey. The Pakistan Development Review, 46(2), 111-128.

Arif, G. M., Iqbal, N., \& Farooq, S. (2011). The persistence and transition of rural poverty in Pakistan: 1998-2004. PIDE Working Papers \& Research Reports, 74, 1-27.

Ali, A., \& Ali, S. (2018). Determinants of poverty in Pakistan. Pakistan Journal of Humanities and Social Sciences Research, 1(2), 17-31.

Awan, M. S., \& Iqbal, N. (2010). Determinants of urban poverty: The case of medium sized city in Pakistan. PIDE Working Papers, 60, 1-22.

Awan, M. S., \& Iqbal, N. (2014). Determinants of urban poverty: The case of medium sized city in Pakistan. The Pakistan Development Review, 54(4), 719-737.

Azid, T. \& Malik, S. (2000). Impact of village-specific, household-specific, and technological variables on poverty in Punjab. The Pakistan Development Review, 39(4), 793-806. 
Bashir, F., \& Idrees, M. (2018). Addressing the pitfalls of single poverty line in the estimation of poverty in different regions of Pakistan. Forman Journal of Economic Studies, 14, 81-102.

Chaudhary, A. R., Iqbal, A., \& Gillani, S. Y. M. (2009). The nexus between higher education and economic growth: An empirical investigation for Pakistan. Pakistan Journal of Commerce and Social Sciences, 3, 1-9.

Chaudhry, I. S. (2009). Poverty alleviation in southern Punjab (Pakistan): An empirical evidence from the project area of Asian Development Bank. International Research Journal of Finance and Economics, 23(23), 23-32.

Cheema, A. R., \& Sial, M. H. (2012). Poverty, income inequality, and growth in Pakistan: A pooled regression analysis. The Lahore Journal of Economics, 17(2), 137-157.

Cheema, A. R., \& Sial, M. H. (2014). Poverty and its economic determinants in Pakistan: Evidence from PSLM 2010-11. Asian Journal of Research in Social Sciences and Humanities, 4(7), 306-326.

Frank, M. W. (2009). Inequality and growth in the United States: Evidence from a New State level panel of income inequality measures. Economic Inquiry, 47(1), 55-68.

Geda, A., de Jong, N., Kimenyi, M. S., \& Mwabu, G. (2005). Determinants of poverty in Kenya: A household level analysis. University Connecticut Economics Working Papers, 200544, 1-25.

Hashmi, A. A., Sial, M. H., Hashmi, M. H., \& Anwar, T. (2008). Trends and determinants of rural poverty: A logistic regression analysis of selected districts of Punjab. The Pakistan Development Review, 47(4), 909-923.

Haq, R. (2005). An analysis of poverty at the local level. The Pakistan Development Review, 44(2), 1093-1109.

Haq, M. A. U., Ayub, K., \& Ullah, M. I. (2015). Micro-level determinants of rural poverty in Pakistan. International Journal of Scientific and Research Publications, 5(2), 1-4.

Haughton, J., \& Khandker, S. R. (2009). Handbook on Poverty+ Inequality. World Bank Publications.

Idrees, M. (2017). Poverty in Pakistan: A region-specific analysis. The Lahore Journal of Economics, 22(2), 139-163. 
Irfan, M. (2011). Remittances and poverty linkages in Pakistan: Evidence and some suggestions for further analysis. PIDE Working Papers, 78, 1-18.

Jamal, H. (2005). In search of poverty predictors: The case of urban and rural Pakistan. The Pakistan Development Review, 44(1), 37-55.

Jamal, H. (2015). Predicting sub-national poverty incidence for Pakistan. Social Policy and Development Centre, Research Report, 85.

Kemal, A. R., Irfan, M., \& Arif, G. M. (2001). MIMAP synthesis report: Major conclusions and policy implications. MIMAP Technical Paper Series, 3, 142 .

Khalid, U., \& Akhtar, S. (2011). Poverty dynamics of female-headed households in Pakistan: Evidence from PIHS 2000-01 and PSLM 2004-05. PIDE Working Papers \& Research Reports, 80, 1-20.

Khalid, U., Shahnaz, L., \& Bibi, H. (2005). Determinants of poverty in Pakistan: A multinomial logit approach. The Lahore Journal of Economics, 10(1), 6581.

Khatun, R. (2015). The impact of micro-level determinants of poverty in Bangladesh: A field survey. International Journal of Research in Management \& Business Studies, 2(2), 1-13.

Khurram, S., \& Hassan, M. U. (2019). Exploring the incidence and correlates of rural poverty in Pakistan. Pakistan Economic and Social Review, 57(1), 69.

Lazear, E. P., \& Rosen, S. (1981). Rank-order tournaments as optimum labor contracts. Journal of Political Economy, 89(5), 841-864.

Mahmood, S., Sheikh, K. H., Mahmood, T., \& Malik, M. H. (1991). Food poverty and its causes in Pakistan. The Pakistan Development Review, 30(4), 821834.

Majeed, M. T., \& Malik, M. N. (2015). Determinants of household poverty: Empirical evidence from Pakistan. The Pakistan Development Review, 54(4), 701-717.

McCullagh, P., \& Nelder, J. A. (1989). Generalized Linear Models (Second Edition). Chapman and Hall.

McKnight, A., Duque, M., \& Rucci, M. (2017). Double trouble: A review of the relationship between UK poverty and economic inequality. Centre for Analysis of Social Exclusion, OXFAM. 
Nasir, Z. M., \& Nazli, H. (2000). Education and earnings in Pakistan. PIDE Working Paper, 177.

Naz, I., Ali, S., \& Aziz, B. (2010). Dynamics of poverty in rural Punjab: A case study of rural area of tehsil Samundri. Forman Journal of Economic Studies, 6, 85- 102.

Government of Pakistan. (2017). Economic Survey (2017-2018). Ministry of Finance: Islamabad.

Government of Pakistan. (2015). Household Integrated Economic Survey (20152016). Pakistan Bureau of Statistics: Islamabad.

Pervez. S., \& Rizvi, S.B. (2014). An empirical analysis on determinants of poverty: A co-integration analysis. Journal of Global and Science, 2, 1-5.

Psacharopoulos, G., \& Woodhall, M. (1993). Education for Development. Oxford University Press.

Qureshi, S. K., \& Arif, G. M. (2001). Profile of Poverty in Pakistan, 1998-99. Pakistan Institute of Development Economics: Islamabad.

Rao, V. M. (1969). Two decompositions of concentration ratio. Journal of the Royal Statistical Society, 132(3), 418-425.

Shaikh, P. A., Ahmed, M., Yousaf, H., \& Ahmed, J. (2020). The determinants of poverty: A case study of district Lasbela, Balochistan, Pakistan. International Journal of Advanced Science and Technology, 29(7), 96889700 .

Shirazi, N. S. (1995). Determinants of Poverty in Pakistan. Pakistan Economic and Social Review, 33(1), 91-101.

Simler, K., Harrower, S., \& Massingarela, C. (2004). Estimating poverty indices from simple indicator surveys. Proceedings of the Centre for the Study of African Economies, University of Oxford, 21-45.

Yetna, P., Wodon, Q., Mungai, R., \& Tsimpo, C. (2012). Poverty in Liberia: Level, profile, and determinants. Poverty and the Policy Response to the Economic Crisis in Liberia, World Bank, Washington, DC, 9-34. 
Correlates Of Poverty in Pakistan: A Rural-Urban Comparative Analysis

\section{Appendix}

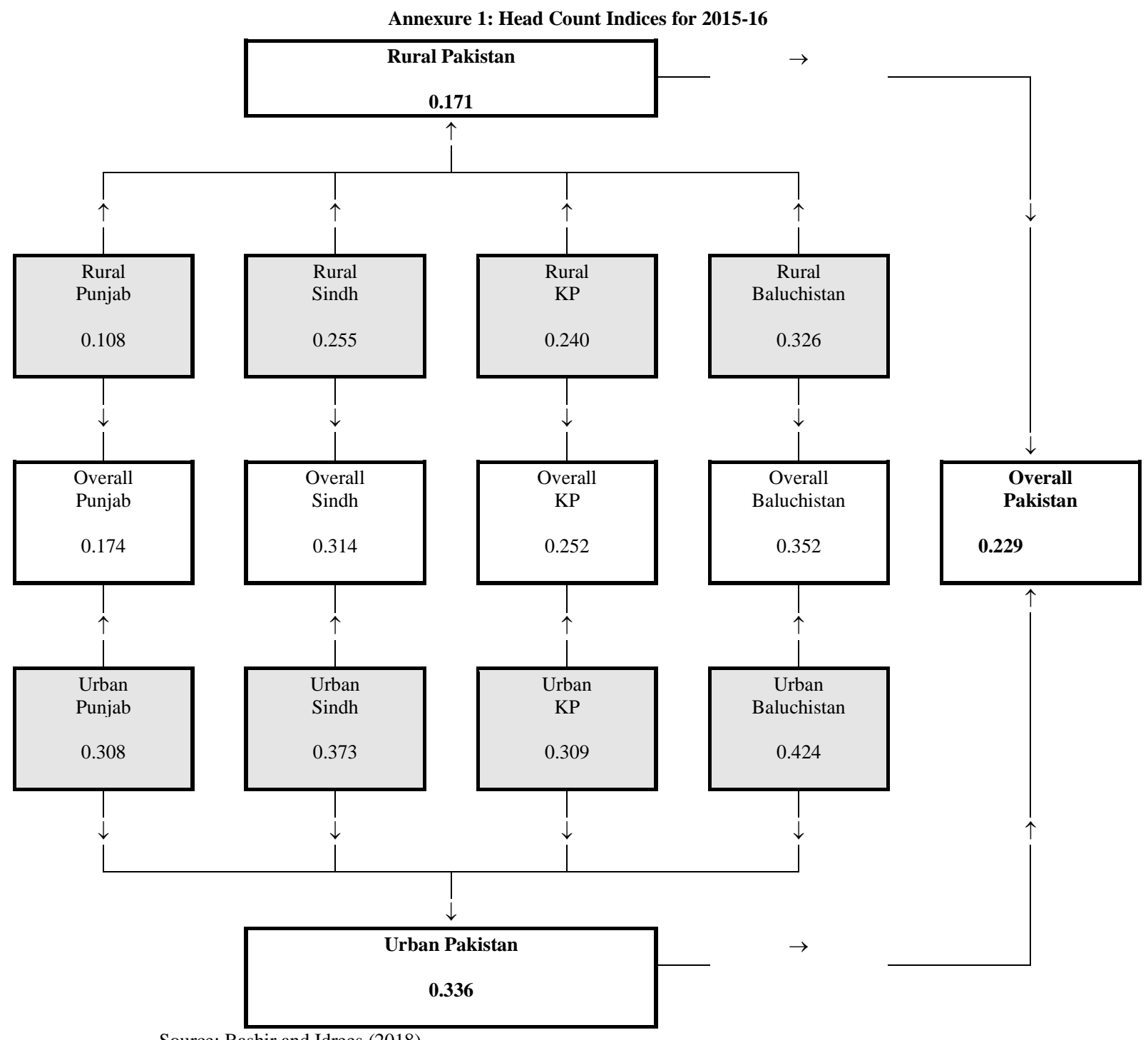

Source: Bashir and Idrees (2018) 